Article

\title{
Science Slams as Edutainment: A Reception Study
}

\author{
Philipp Niemann ${ }^{1, *}$, Laura Bittner ${ }^{2}$, Philipp Schrögel ${ }^{2}$ and Christiane Hauser ${ }^{2}$ \\ ${ }^{1}$ National Institute for Science Communication gGmbH (NaWik), 69118 Heidelberg, Germany; E-Mail: niemann@nawik.de \\ 2 Department for Science Communication, Institute of Technology Futures, Karlsruhe Institute of Technology, \\ 76131 Karlsruhe, Germany; E-Mails: laura.bittner@kit.edu (L.B.), philipp.schroegel@kit.edu (P.S.), \\ christiane.hauser@kit.edu (C.H.) \\ * Corresponding author
}

Submitted: 14 September 2019 | Accepted: 17 January 2020 | Published: 18 March 2020

\begin{abstract}
Science slams are a prominent form of science communication especially in Germany that seeks to entertain. While some view science slams as an excellent vehicle for disseminating knowledge, others argue that the imperative to entertain undermines the scientific value of this form of presentation. Drawing on empirical data from three science slam events, this explorative study examines how audiences and presenters perceive the science slam, particularly as it relates to entertainment and the communication of scientific knowledge. Our multi-method analysis includes audience surveys $(n=469)$, an eye-tracking study, and interviews with science slammers $(n=18)$. Our results show that the main reason audiences attend a science slam is for entertainment, yet they also have a strong interest in scientific content. Assessing the slammers' aspirations concerning the audience, we find entertainment to be an important part, but the motivation to impart scientific knowledge is key for most. When asked to evaluate individual presentations ( $n=20)$, spectators tended to rate both the entertainment and scientific value of the presentations as high. However, in terms of visual attention within individual presentations, spectators spent more time considering scientific content than entertainment content. Overall, we do not find evidence for the common claim that the focus on entertainment undermines the scientific value of science slam presentations - rather, entertainment and scientific content are combined to produce "edutainment" in a positive sense.
\end{abstract}

\section{Keywords}

entertainment; eye-tracking; presentation forms; science communication; science slam

\section{Issue}

This article is part of the issue "Emotions and Emotional Appeals in Science Communication" edited by Monika Taddicken (Technische Universität Braunschweig, Germany) and Anne Reif (Technische Universität Braunschweig, Germany).

(C) 2020 by the authors; licensee Cogitatio (Lisbon, Portugal). This article is licensed under a Creative Commons Attribution 4.0 International License (CC BY).

\section{Introduction}

A science slam is a presentation competition in which scientists-typically doctoral students-showcase their own research. It is a form of science communication that seeks to entertain (Niemann, Schrögel, \& Hauser, 2017, pp. 103-108). This combination of science and entertainment, often subsumed under the term "edutainment," is seen by some as an opportunity for science communication to appeal to a wider audience (Eisenbarth \& Weißkopf, 2012, p. 162). However, other individuals view science slams rather critically, arguing that the imperative to entertain naturally undercuts the scientific and pedagogic value of the form (Griem, 2018, p. 3; Klaue, 2015 , p. 543). To date, the participants in this debate have mainly relied on normative assertions unsupported by empirical data. This article seeks to remedy the lack of empirical data in this area. In doing so, it focuses on an explorative study on spectators as the recipients of science slam presentations. The analysis considers the general motivations and expectations of the spectators as well as their assessment of individual presentations. Special attention is devoted to effects that emerge from presentational aspects that seek to entertain.

Although the focus of this study is on the reception of a specific science communication form by individ- 
ual spectators-especially concentrating on the aspect of entertainment-it also addresses a general research deficit that is described by Weingart and Joubert (2019, p. 5): "Evaluations of different science communication formats are...rare and inaccessible although the respective organisations stress their importance." When looking at the evaluation of specific science events, there are hints that entertainment (often addressed as "fun" or "enjoyment," cf. Section 2.2) is an important motivation for people attending these events (e.g., for science festivals, see Canovan, 2019; Jensen \& Buckley, 2014), but these studies usually do not analyse what is perceived as entertaining or how expectations and experiences match. These research gaps are addressed in this study with regard to science slams.

\section{Science Communication and Science Slams}

A science slam consists of a series of entertaining and easily understandable talks that are usually limited to ten minutes in length. At the end of the event, a winner is chosen based on audience voting (Eisenbarth \& Weißkopf, 2012). The science slam is based on the poetry slam-a presentation competition for literary texts (Wildemann, 2011). While the first science slam in Germany was held in 2006, there are now 58 regular science slam event series in the country, most of which are supported by research organizations and initiatives (Schrögel, Niemann, Bittner, \& Hauser, 2017, p. 3).

One defining feature of the science slam is the event format and setting. Usually, the science slam takes the form of a hosted evening event outside of scientific institutions-for example, at clubs or cultural centresin order to distinguish them from traditional academic lectures (Hill, 2015). Furthermore, the mode of presentation is unique: participants seek to present their own research (e.g., a doctoral thesis) in a clearly understandable and compelling way. Indeed, the entertainment value of the presentation is a key concern, which is why "slammers" usually put a great deal of effort into the design of their presentations. While there are no real restrictions on presentation aids, the de facto standard is creative and humorous PowerPoint slides (Schrögel et al., 2017, p. 3).

While the science slam is primarily a phenomenon in German-speaking countries and has only recently gained more international presence (Lederman, 2016) there are some similarities to other, more international forms. One of them is e.g., famelab, an international presentation competition for students and young researchers in science, technology, and engineering (Zarkadakis, 2010). Major differences to science slams are that famelab presentations have a stricter time limit (only three minutes) and more limits to presentation techniques (e.g., no slides allowed). TED and TEDx Talks are other presentations forms that differ from science slams in not being primarily focused on science topics and following a more uniform presentation style, which is evoked by guidelines and mandatory presentation training (Anderson, 2016; Sugimoto et al., 2013).

\subsection{Science Slams as a Form of Presentation}

Science slams are a multimodal form of science communication in which the spoken word of the presenter is supplemented with other communicative modes such as imagery, video, audio, written text, and gestures or facial expressions (Bucher, Niemann, \& Krieg, 2010, p. 376). Analytically, we can differentiate between three presentational modal domains: the mode of the speaker's spoken language; the visual mode (e.g., image, text, design); and the performative mode (e.g., the speaker's pointing actions or facial expressions; Bucher \& Niemann, 2015, p. 76). Usually, all three of these presentational modal domains are combined in PowerPoint presentations.

In order to distinguish between forms of presentation in science communication, Niemann et al. (2017) proposes four classification parameters: the degree of multimodality; the degree of interactivity; the degree of performance; and the degree of "event and entertainment orientation." Drawing on this typology, Niemann, Bittner, Hauser, and Schrögel (in press) conduct a detailed analysis of science slams, concluding that the science slam is primarily characterized by a very high degree of "event and entertainment orientation." However, science slam presentations can also exhibit a high degree of multimodality, interactivity, and performance, depending on the individual presentation in question (Niemann et al., in press).

\subsection{Entertainment as "Pleasure" and "Appreciation"}

In the public discussion of science slams, critics repeatedly underscore how the imperative to entertain can be at odds with the aim to educate and to inform (Griem, 2018; Thiel, 2018, p. 3). Klaue (2015, p. 543) even speaks of a "mixture of populism, hubris, and witlessness," contending that slammers believe "the sciences can only be brought closer to the masses if one adapts to their limited everyday understanding, simplicity, and need for entertainment."

Against the backdrop of such partial polemical attacks, this article seeks to shed light on the tension between entertainment on the one side and scientific content on the other. How does the audience perceive this combination of entertainment and science, commonly referred to as "edutainment"? What relevance does entertainment have for the audience's expectations concerning this form of presentation? And what role does entertainment as well as scientific knowledge play in the reception of individual science slam presentations? To answer this last question, we carefully examine the entertainment potential of science slams in addition to their specific scientific content. To complete the picture, we also explore how slammers and audience members perceive the science slam as a vehicle for entertaining and informing. 
First, however, the concept of "edutainment," as well as the underlying concept of entertainment, must be clarified. Edutainment-as well as the concept of infotainment in a mass media context (Wirth, 2014)-is an umbrella term describing various approaches that combine education and entertainment. It can be traced back to the pedagogic concept of "experiential learning" (Nahrstedt, 2002, p. 152), but lacks a detailed definition. While various definitions can be found in the pedagogic literature, the term usually refers to a form of education that seeks to captivate, instil excitement and evoke emotions-a "rousing of learners' feelings" as Aksakal (2015, p. 1233) puts it. However, the combination of education and entertainment is not unanimously seen as positive (Okan, 2003).

The term "entertainment" also lacks a clear-cut definition in the communication sciences and reception research, prompting Vorderer and Reinecke $(2012$, p. 20) to remark "that the description and explanation of (entertainment) has remained under-differentiated." It seems clear that entertainment consists of more than just emotions such as joy or happiness, that it does have "emotional components" (Wirth \& Schramm, 2005, p. 14). Wirth (2014, p. 61) even sees entertainment as a "metaemotion" that arises as a reaction to other emotions. A commonly accepted definition is to view entertainment as "hedonic entertainment" - an experience that primarily aims to engender feelings of well-being "in the sense of pleasure" (Vorderer \& Reinecke, 2012, p. 18). Furthermore, more recent research (Schramm, 2019, p. 48) assumes a further, more complex and more intensive form of entertainment experience (non-hedonic), which can be characterized by the term "appreciation" (Vorderer \& Reinecke, 2012, 2015). It remains controversial whether this is about "satisfaction of basic needs" or a "sensation of personal significance triggered by reception (>Meaningfulness $<$ )" (Vorderer \& Reinecke, 2012, p. 21).

Empirical reception studies on the experience of entertainment are scarce and have so far been published primarily in the field of political entertainment research (e.g., Schneider, Bartsch, \& Gleich, 2015; Weinmann, 2019).

Referring to a hedonic conception of entertainment, Wirth and Schramm (2005, p. 14) state: "In this way, the layperson's understanding is not too far away from what our science has found out about the phenomenon of 'entertainment' so far." Thus, we assume that visitors to science slams generally understand "entertainment" in the hedonic sense of the term.

Especially when talking about a hedonic, joyful entertainment experience, there is another terminus to be considered: humour. Similarly to entertainment, the concept of humour is rather easily accessible with a heuristic understanding, but difficult to grasp with a theory-based definition (Goldstein \& McGhee, 1972; Veatch, 1998). The specific effects of humour in science communication have been studied for written forms of communi- cation (Pinto \& Riesch, 2017) as well as for live comedy presentations (Pinto, Marçal, \& Vaz, 2015). The results of these studies as well as theoretical considerations (Riesch, 2015) show a heterogeneous picture: While humour can have a positive impact on the reception of scientific presentations or articles, it can sometimes also invoke negative reactions.

\subsection{Reception as Interaction}

In addition to exploring what audiences expect from science slams, our research is concerned with the reception of individual science slam presentations. Our theoretical basis is a concept of reception based on an interactional theory that was developed by Bucher (2012). For Bucher, reception is a "regular, competencebased and supply-dependent sequence of acts of appropriation" (Bucher, 2005, p. 91), in which active userscomparable to a traditional face-to-face conversationenter into a quasi-dialogical exchange with media content, or, in this specific case, with a science slam presentation (Bucher, 2012, p. 24; Niemann, 2015, p. 40). Key to this approach is the concept of attention integrating intentional (schema-based) and non-intentional (salient-based) forms of attention (Bucher \& Niemann, 2012; Bucher \& Schumacher, 2006).

To what extent can the "appropriation process" performed by audiences be ascribed to those elements of the science slam presentation that have the potential to entertain? In principle, this can involve all elements of the presentations, such as images or the text parts on PowerPoint slides, verbal expressions by the slammers or props they use. To operationalize such an understanding of reception within the framework of an empirical study, we require a method that directly considers the moment of contact between science slam presentations and recipients, and is thus able to shed light on this quasidialogical process of appropriation. In other words, the method has to allow for analysing the recipients' allocation of attention (cf. Section 4).

\section{Data and Research Questions}

In order to conduct a detailed investigation of the reception of science slams, we selected events that allow generalizable statements about this form of presentation. Specifically, we chose the final event of the 2016 German Science Slam Championships and a Best-Of Event (which were attended by renowned slammers), both took place in Darmstadt, December 2016. In addition, a further event was selected that can be described as a "normal" science slam (with novice and experienced slammers). The latter event took place in February 2017 in Karlsruhe. Overall, the corpus consists of twenty individual presentations. In the following sections, we devote special attention to a single presentation - the talk given by Reinhard Remfort as part of the Best-Of Event in Darmstadt-in order to conduct 
a more in-depth analysis. This example has been chosen since he can be considered an experienced and generally well-received slammer (e.g., German science slam champion 2013). In addition, being a male science slammer from the natural sciences-specifically physics-he represents a major share of the current slammer's community (Schmermund, 2018).

Studying these events, we focused on the following three research questions-each specifically regarding the role of scientific content and entertainment:

RQ1: What are the general motivations and expectations of science slam audiences?

RQ2: How do these fit with the ideas that the science slammers themselves associate with this form of science communication?

RQ3: How do spectators perceive individual science slam presentations?

\section{Research Methods}

To address the questions, we used an explorative multimethod design. We conducted audience surveys, and also interviewed the slammers. To record the appropriation process at the moment of contact between presentations and recipients, we recorded eye movements, which can be interpreted as indicators of attention (Bente, 2004, p. 298).

To address the general motivations and expectations (RQ1), the science slam audiences were asked to participate in a survey. Audience surveys are a common method for evaluating science communication activities (Boyette \& Ramsey, 2019; Canovan, 2019; Jensen \& Buckley, 2014). The audience surveys in our study were conducted by means of a standardized written survey. At each of the three science slam events, 100 paper questionnaires were distributed. In addition, flyers with invitations to participate in the same questionnaire (except the questions regarding individual presentations to be filled out directly after each talk) in an online format were distributed to the rest of the audience to broaden the data basis for the overall assessment. In each case, between 73 and 90 paper questionnaires were returned, while the number of completed online questionnaires was between 23 and 143. A comparison of the paper and online questionnaires revealed no significant differences in terms of sociodemographic characteristics or response behaviour. Accordingly, all data sets were evaluated together $(n=469)$. Specifically relevant for RQ1, the science slam audiences answered the question "how important were the following aspects in your decision to come to the science slam/to the TEDxKIT Event/famelab today" on a scale with five options ranging from "very important" to "not important at all."

To put the motivations and expectations of the audiences into context, we also assessed the presenters' view on the task of communicating their findings. Also, here their view on the tension between scientific content and entertainment (RQ2) was of particular interest. For this purpose, semi-structured interviews were conducted with 18 of the 20 science slammers that participated in the science slam events.

The assessment of individual science slam presentations concerning the entertainment and informational value (RQ3) was measured by means of the audience survey. Recipients answered the questions "how do you rate the information content of the presentation" and "how do you rate the entertainment value of the presentation?" Both items were measured on a scale with five options ranging from "very good" to "inadequate." Respondents could choose "unable to answer."

To analyse the spectators' immediate perception of the individual science slam presentations (RQ3), gaze recordings of selected participants were conducted at the three science slam events. Among other things, eye movements provide information on the recipients' selection and inference strategies, as well as on the attention and interest they devote to individual presentation elements, including those designed to entertain, which is the particular focus of this study (cf. on PowerPoint presentations Bucher et al., 2010, p. 385). Following the eye mind assumption (Just \& Carpenter, 1980) and the critical reflection of this approach (Geise, 2011; Schumacher, 2012), the fixation of elements, as measured by an eye tracker, allows for a drawing of inferences on potential cognitive processing. However, to assess the actual processing of information, additional methods would be necessary (Schumacher, 2012, pp. 115-116).

Using eye-tracking in reception research that is based on an interactional theory is a well-established method in communication science in general (e.g., Gehl, 2013; Niemann, 2015; Schumacher, 2009) as well as specifically in science communication research (e.g., Böhmert, Niemann, Hansen-Schirra, \& Nitzke, in press; Bucher \& Niemann, 2012, 2015; Niemann \& Krieg, 2011). For several years now, the method is gaining importance in science communication research resting upon other theoretical backgrounds (e.g., Kessler \& Zillich, 2018; Rotboim, Hershkovitz, \& Laventman, 2019). In this study, one to two randomly selected people from the audience were asked to wear mobile eye-tracking glasses (SMI Eye Tracking Glasses) for two to three presentations at each event. After a technical pre-assessment of the material regarding data quality, gaze recordings for a total of nine presentations remained for further analysis. To make statements about the distribution of attention between those parts of the presentations that can be attributed to entertainment and those that consist of scientific content, specified areas of interest (AOIs) were generated (cf. Section 5.2.2) prior to the analysis of the gaze data. The essential measurement used in the analysis of the gaze data is the "viewing rate," i.e., the gaze time as percentage of the total reception time recipients spend on these (AOIs). 


\section{Results}

\subsection{Audience's Expectations and Motivations of the Science Slammers}

The audience that attended the three science slam events was similar in terms of sociodemographic characteristics. With a view to completed questionnaires, the majority of participants were male (56.2\%). The average age was 31 years. The best represented age group was 21 to 30 years. The spectators were more educated than the average population. The vast majority had a university entrance qualification or higher $(81.2 \%$ in total, of which $24.7 \%$ had a university entrance qualification, $56.5 \%$ a university degree, and $8.5 \%$ a doctorate).

This suggests that science slam events are particularly attended by highly educated recipients who actively come into contact with the science system or have come into contact with it through their education. The stated interest in science corroborates this interpretation. Among attendees, more than half of those surveyed (56.9\%) answered that they were very interested in science, while another third said they were "rather interested."

When asked about the relevance of different aspects for their decision to attend the science slam event (RQ1), four-fifths of the respondents stated their interest in science as "very important" or "important." Yet the expectation to be entertained was even more important: Almost two-thirds of the respondents (63.2\%) cited this as a very important reason for their visit, while another third (32\%) viewed it as an important reason (Figure 1). The identified differences are statistically sig- nificant (based on a paired sample t-test), even if the effect size is small (Cohen's $d=0.417$ [Cohen, 1988, p. 40]; $T=-8.729, \mathrm{df}=437$ /interest in science: $M=1.84$, SD $=0.861$; entertainment: $M=1.42, S D=0.632$ ). By contrast, the opportunity to learn something was a less relevant factor (very important: $22.5 \%$, important: $38.4 \%$ ). Furthermore, the effect size was small when comparing the differences between interest in science and learning $(\mathrm{d}=0.419, \mathrm{~T}=-8.787, \mathrm{df}=437 /$ interest in science: $M=1.84, S D=0.861$; learning: $M=2.30$ $\mathrm{SD}=0.979$ ) and of medium strength when comparing the differences between entertainment and learning $(d=0.781, T=-16.344, d f=437 /$ entertainment: $M=1.42, S D=0.632$; learning: $M=2.30 S D=0.979$ ). These findings correspond with the audience assessment of science festivals as studied by Jensen and Buckley (2014, p. 565). They find that creating interest ("exciting, colourful, creative, unusual, inspiring, bright"-falling into our category of entertainment) is the dominant aspect, but gaining knowledge is still relevant.

When looking at the comparable science communication forms famelab and TEDx (Figure 1), some aspects of audience expectations differ while others are rather similar to expectations regarding science slams:

- Interest in science: The interest in science as a reason for visiting these forms is somewhat higher than reported for science slams. This assessment is based on data collected at a famelab and a TEDx event in Karlsruhe in 2017. Statistically significant differences based on independent samples t-tests can be seen only to the TEDx event, but the effects are small $(d=0.304 ; T=1.155, d f=530 /$ sci-

Reasons for attending various events

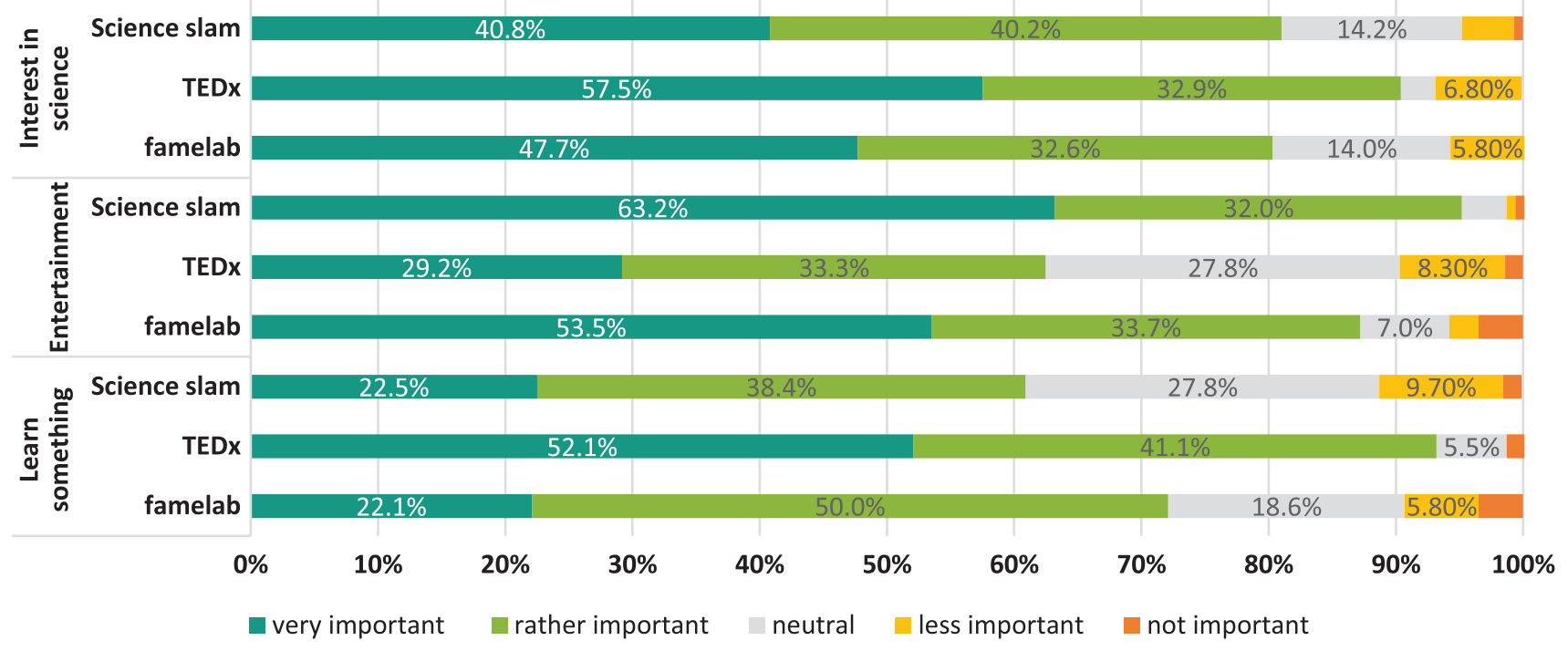

Figure 1. How important were the following aspects in your decision to come to the science slam/to the TEDxKIT Event/famelab today? Notes: Science slam: $444 \leq n \leq 458$; TEDx: $72 \leq n \leq 73$; famelab: $n=86$ ). Values $<5 \%$ are not specified due to clarity reasons. 
ence slam: $M=1.84, S D=0.866$; TEDx: $M=1.58$, $\mathrm{SD}=0.844)$.

- Interest in entertainment: The comparison with these other forms also confirms the strong focus of science slam visitors on the entertainment aspect. However, the differences between the individual forms (all significant, $p=0.05$ ) vary in size: Although there is a significant difference between the science slam and famelab events in terms of entertainment experience, this is only small with an effect strength of $d=0.303$ ( $T=-2.967$, $\mathrm{df}=540 /$ science slam: $\mathrm{M}=1.44, \mathrm{SD}=0.66$; famelab: $M=1.69, S D=0.961$ ). In contrast, the difference to the TEDx event is more pronounced (strong effect, $d=0.87, T=-8.207, d f=527 /$ science slam: $M=1.44, \mathrm{SD}=0.66 /$ TEDx: $\mathrm{M}=2.18$, SD $=1.005$ ).

- Interest in learning: A strong effect can also be seen when comparing the answers of the visitors of science slam and TEDx events regarding the interest in learning something $(d=0.81, T=5.906$, $\mathrm{df}=525$ /science slam: $\mathrm{M}=2.29, \mathrm{SD}=0.973$; TEDx: $M=1.59, S D=0.739)$ - just vice versa: This aspect is most important for TEDx visitors, while it is regarded as less important by the audience of science slam events. A significant difference between science slam and famelab events could not be observed for this aspect.

In summary, it can be concluded from the audience survey-concerning RQ1-that science slams are strongly associated with entertaining aspects among the audience and that this is also a strong focus in comparison with other forms.

To put these findings into context, after the science slam events, semi-structured phone interviews were conducted with 18 of the 20 science slammers. In these interviews the slammers were asked to explain their reasons for participating and to evaluate their presentations and the science slam form in general with regard to entertainment value and scientific content (RQ2).

While several slammers directly or indirectly voiced the motivation to inform the public about their research and science in general, 12 of them explicitly mentioned the joy of presenting as a major reason for participating: "It is just fun; you don't get so much applause or stadium waves at conferences!" (slammer 15).

Regarding the balance between entertainment and scientific content, the science slammers provided very differentiated and heterogenous assessments. All 18 respondents saw a very close connection between both aspects. As one slammer put it:

Well, I think you don't come [to a science slam] to spend a sad evening, but to have some fun. And I find that the pairing of some scientific content, shown in a playful and entertaining way, is very important. (slammer 11)
Five interviewees did not explicitly rank one aspect over the other. Nine slammers clearly assigned priority to the scientific content:

A science slam has two central goals: I want to impart knowledge and I want to entertain people. In a scientific talk, even for a lay audience, entertainment is at best a secondary goal, which I use to achieve my primary goal, which is to impart knowledge. (slammer 3 )

On the other hand, four interviewees described entertainment as a defining aspect of the science slam and also identified it as the key concern of audiences in some cases, while taking a critical perspective: "I think that entertainment is very important [for a science slam] and the main point of focus....This is a pity, because I think it is sometimes at the expense of content" (slammer 1).

Overall, the slammers had very differentiated and reflective perspectives on the science slam. Regarding their personal motivation, a majority of presenters cite fun and enjoyment. At the same time, another central motivation for many slammers is to impart knowledge and showcase research projects. Entertainment is seen as a tool to attract audiences in the first place and ensure their interest.

\subsection{Entertainment and Informational Value in Individual Science Slam Presentations}

\subsubsection{Audience's Assessment}

The audience members participating in our paper survey (250 in total) were also asked to assess the entertainment and informational value of the twenty individual science slam presentations (RQ3). Our case study, the presentation by Reinhard Remfort (talk no. 4), was rated by the audience as good or better in both respects by an overwhelming majority ( $82.7 \%$ and $76.9 \%$, respectively). At the same time, the audience clearly considered the entertainment value of the presentation as superior to its informational value, with a much higher number of "very good" ratings granted to the entertainment category $(51.9 \%$ versus $32.7 \%)$.

Looking at all 20 science slam presentations, the median percentage of survey participants ranking the entertainment value as "good" or "very good" is $84 \%$ (the median was used instead of the arithmetic mean as a more robust measure against outliers). The median percentage of participants ranking the informational value as "good" or "very good" is $72 \%$ (Figure 2). The assessments of individual talks have a heterogeneous distribution, marked by isolated particularly positive evaluations (e.g., talk no. 3) and isolated less positive evaluations overall (e.g., talk no. 5). In 11 out of 20 presentations the respondents rated the entertainment value more positively than the information value, while the reverse was true in 8 cases. Equal rankings were seen in just one case (talk no. 17).

Examining the difference between the assessments granted to entertainment value and information con- 


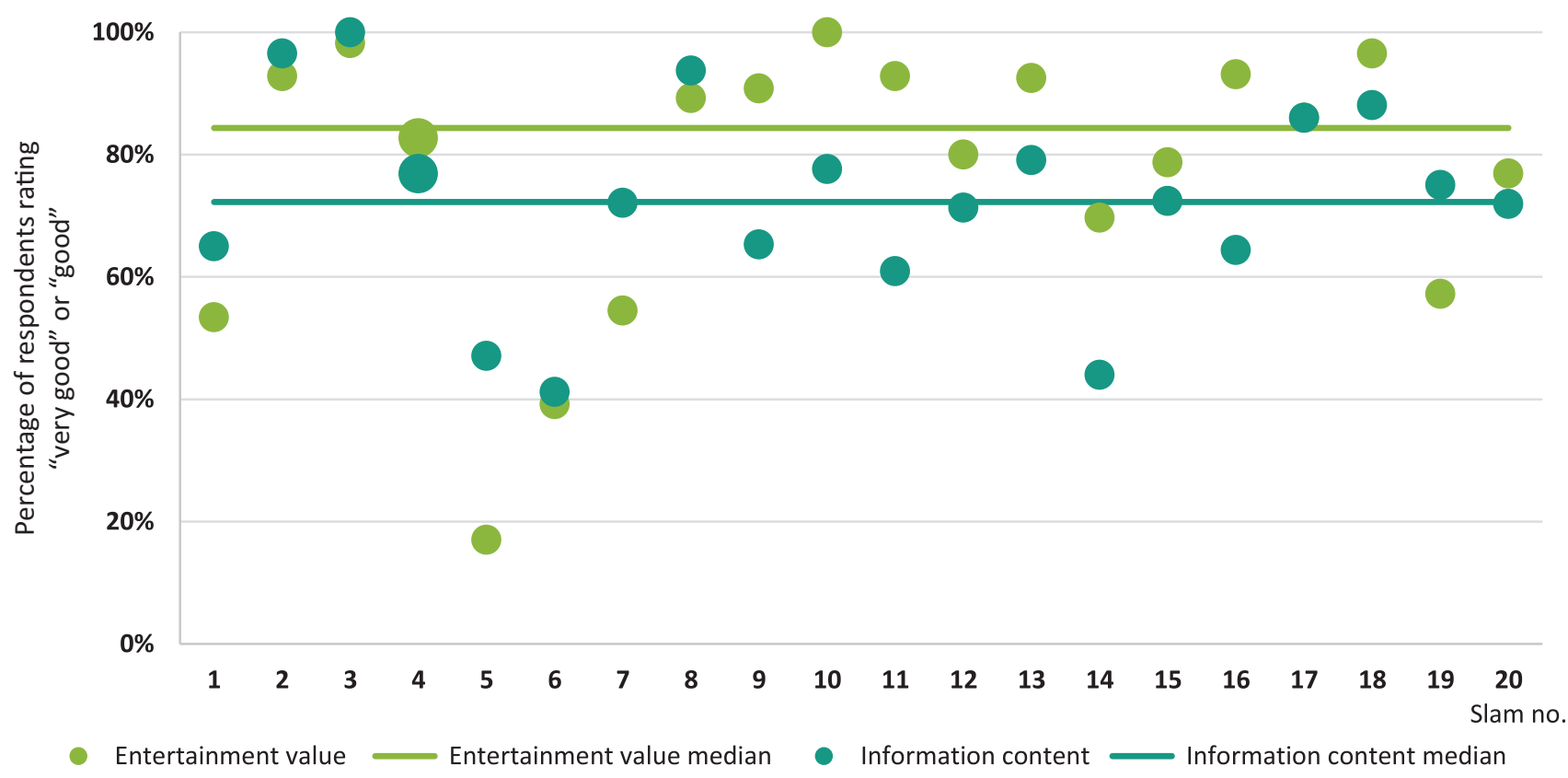

Figure 2. Audience assessment of the entertainment value and the information content of the 20 presentations, both measured as the percentage of survey participants ranking the respective category as either "very good" or "good." Notes: The data points represent the values for each presentation; the medians of both values are drawn as continuous color-coded lines $(51 \leq n \leq 89)$.

tent in paired samples t-tests for each presentation (for a table with all statistical information see Supplementary Material), we find significant divergence in three-quarters of the presentations ( $p<0.05$ ). However, in nine of 20 cases, the effect strength is small $(0.242 \leq d<0.465$; see Supplementary Material for detailed information). Five presentations had an average effect strength $(0.533 \leq d<0.717)$ and only one presentation (no. 16) had a strong effect $(d=0.861)$. In this way, we find divergence between the assessments granted for entertainment value and information content, but they are not particularly pronounced. Accordingly, at least from the perspective of the audience, an entertaining presentation is not necessarily poor in terms of information content or "unscientific."

\subsubsection{Reception Data}

In the following, the relationship between entertainment and information content is examined based on the concrete reception of science slam presentations (RQ3). By analysing the eye-tracking data collected from individual test persons during the science slams events (cf. Section 4), information can be gained about the type of content available for reception as well as about the degree of visual attention and interest in this content among recipients.

Before the eye-tracking data can be evaluated, we must first define specific AOIs (Rotboim et al., 2019, p. 88-89; see Figure 3). For this purpose, we developed a category system that differentiates between various elements of the science slam presentation. This system first differentiates between the human presenter and the PowerPoint slides. The typical approach of segmenting AOls by modal categories (Bucher \& Niemann, 2015, p. 82-83) is not sufficient for our analysis since for example, an image could be either a scientific data visualization or a rather humorous decoration. Elements belonging to the slides were therefore assigned to the categories "science," "hybrid," or "entertainment." "Science" includes all material that would be at home in scientific lectures, diagrams of research data or scientific formulas (Figure 3, dark green). The category "hybrid" includes material which, although related to the topic under discussion, is not normally found in scientific lectures (Figure 3, dark blue), e.g., because of their form of presentation (personal photos, cartoons). Finally, material was classified as "entertainment" if it had little or no relation to the content and was included merely to entertain or embellish (e.g., humorous references to pop cultural phenomena, such as the Telly Tubby in Figure 3).

Based on these AOIs and category assignments, we can calculate the "visibility" of material from each category for the audience as a share of the total presentation time. In the presentation given by Reinhard Remfort, scientific material had a visibility of $60 \%$; by contrast, the corresponding figures for hybrid and entertainment were $48.5 \%$ and $46.2 \%$, respectively (see Figure 5, left part). Accordingly, we do not find support for the common view that science slams neglect scientific content in an effort to merely entertain audiences.

In our analysis of eight other science slam presentations (as shown in Figure 4), we find a similar preponderance of scientific content. 

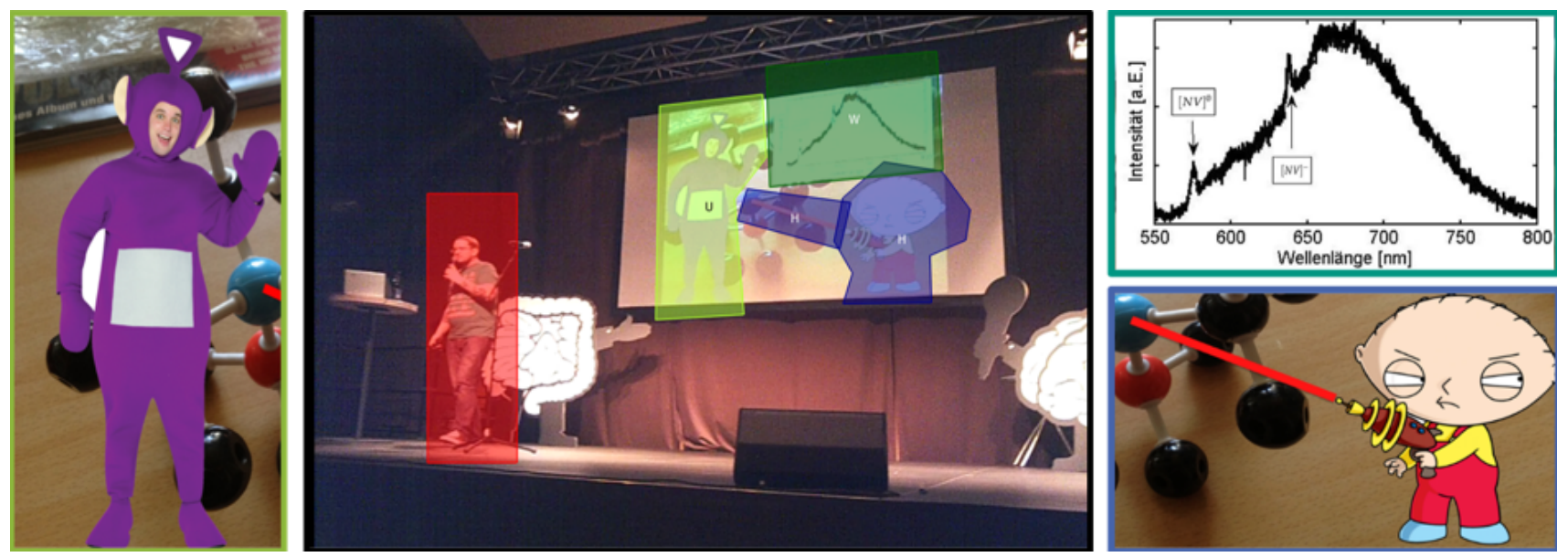

Figure 3. AOls in the talk by Reinhard Remfort. Notes: Examples of material assigned to the categories "science" (dark green, top right), "hybrid" (dark blue, bottom right), and "entertainment" (light green, left). The presenter is marked in red.

Figure 4 also shows two dimensions of the "visibility" of the categories "science," "entertainment," and "hybrid" in the science slam presentations: specifically, the number of elements in a category (the size of the circles), and the average visibility of these elements ( $y$-axis). In the slam by Reinhard Remfort (Figure 4, slam number 4), the hybrid elements (dark blue) were the longest visible, but there were considerably fewer elements in this category than in the categories science (dark green) and entertainment (light green). Although the number of elements in these latter two categories is roughly the same in his presentation, the scientific elements were visible for much longer. Material from the entertainment category had the shortest visibility duration.

In general, these findings also applied to the other science slam presentations: In the eight other slams, entertainment material had the shortest average visibility duration, regardless of the number of coded elements. By contrast, the scientific material had a longer average visibility and was also predominant in terms of total numbers. Only two slams-15 and 19-diverged from the norm due to their remarkably high number of hybrid elements (Figure 4). These two presentations had a similar format: they used slides in a cartoon style, personally drawn by the slammer.

The so-called "viewing rate" is a tool for assessing the reception behaviour of science slam audiences. The viewing rate (gaze time as percentage of total reception time) expresses how long the presenter or an element from the aforementioned categories was actually viewed by recipients. It thus provides "information about the degree of attention and interest" (Bucher et al., 2010, p. 385) for this element. In Reinhard Remfort's slam, the most attention (26.2\%) was paid to the presenter

Average visibility in [ms]

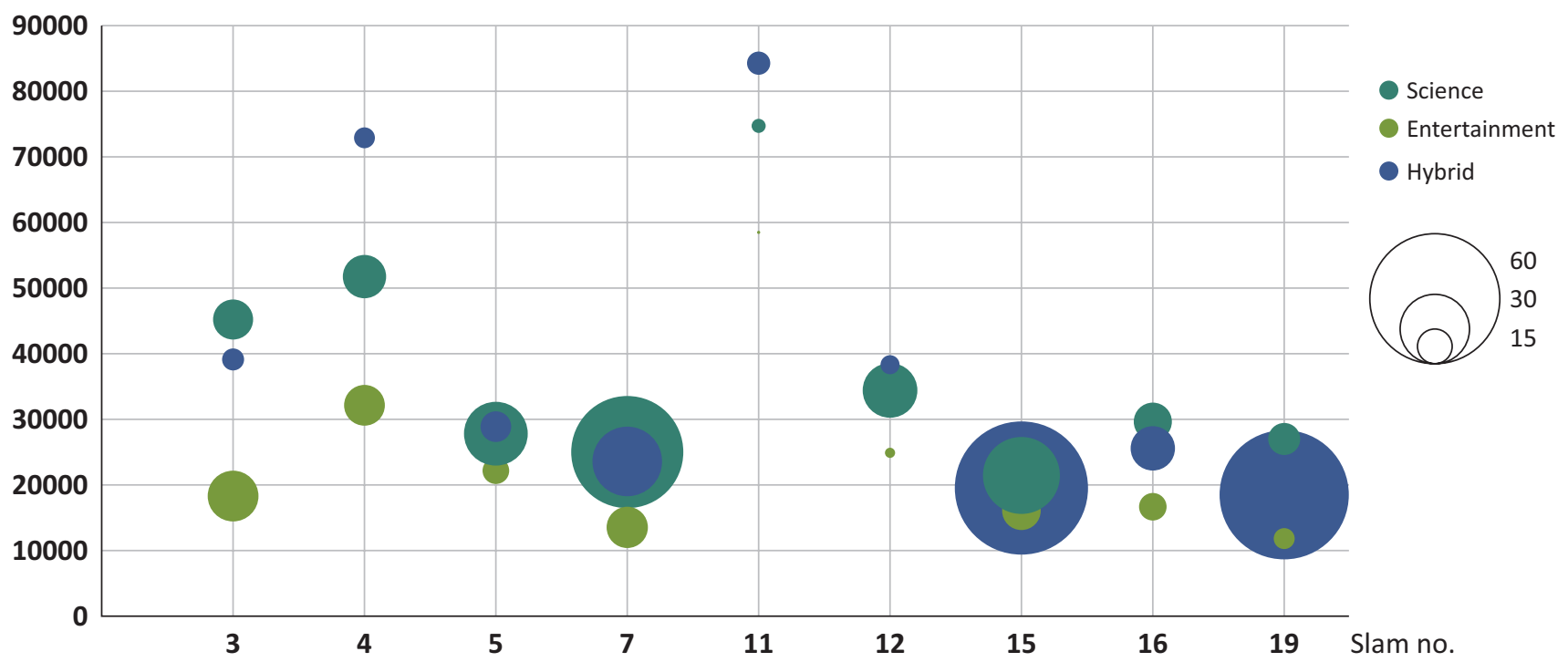

Figure 4. Average visibility of the elements attributed to the three AOI categories in 9 different science slam presentations. Notes: The numbering corresponds to that in Figure 2. The size of the circles denotes the number of elements in a category. 


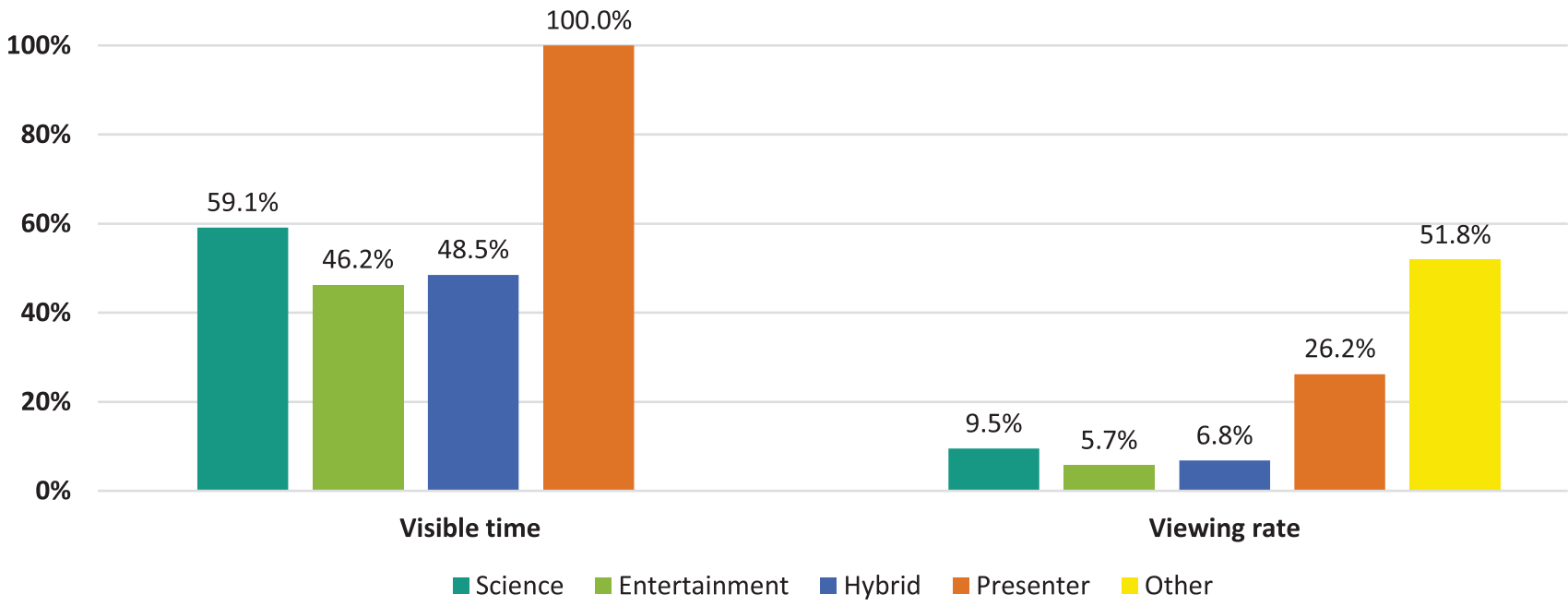

Figure 5. Cumulative visible time (as percentage of total reception time) and viewing rate (gaze time on visible elements as percentage of total reception time) for the three categories and the presenter in the presentation by Reinhard Remfort. Note: The category "other" in the section viewing rate includes gazes on all other, unclassified elements in the scenery.

(Figure 5, right part). With regard to the PowerPoint slides, we find a clear relationship between visible time and viewing rates: The scientific elements received the most attention (9.5\%), followed by the hybrid material $(6.8 \%)$. Meanwhile, the entertainment material received the least attention $(5.7 \%)$. The remaining gaze time ("other") consisted of gazes outside the defined AOIs (e.g., background, audience).

The other science slam presentations show a similar tendency. Due to the data quality, in addition to the slam of Reinhard Remfort (slam no. 4), only five other presentations were considered in this part of the analysis: two from the Best-Of Event in Darmstadt $(3,5)$, and three from the 2016 German Science Slam Championship $(7,11,12)$.
In half of the science slam talks, the presenter received the most attention (slam no. 7, 11, 12), in the other half the majority of visual attention was diverted to areas not related to the presentation (slam no. 3, 4, 5). If we discount these other areas and the presenter and only consider the contents of the PowerPoint slides, the category of science received the most attention in five of the six presentations. Also in five cases, entertainment elements received the least attention. Hybrid elements ranked in between. In talk 11, we find a remarkable picture: Hybrid content received by far the most attention. It should be noted that among the six presentations considered here, talk 11 was the presentation with the fewest PowerPoint slides and the lowest number of slide elements in the three categories. In addition, 65\%

$60 \%$

$50 \%$

$40 \%$

$30 \%$

$20 \%$

$10 \%$

$0 \%$

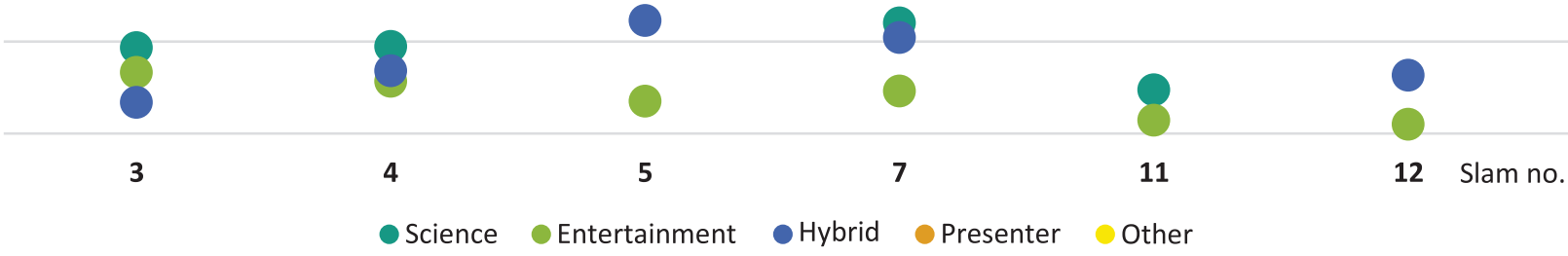

Figure 6. Viewing rate (gaze time on visible elements as percentage of total reception time) for the three AOI categories, the presenter and "other" unclassified elements in the scenery in six science slam presentations. Note: The numbering of the slams corresponds to that in Figure 2, the presentation by Reinhard Remfort is slam no. 4. 
of the slide elements of talk 11 were attributable to the hybrid or entertainment categories, with entertainment only accounting for one element. As talk 11 was an outlier, we excluded it from the following analysis.

When watching a presentation, individual elements can be viewed more than once and in alternating succession. In order to take this into account and draw conclusions about the reception of the talks beyond cumulative gaze time, we also considered how long the recipients focused on one element per individual viewing. In light of our research questions, the duration of focus on scientific and entertainment material is of particular interest. In order to exclude shorter gaze times-as occurs, for example, if an element is merely glanced at momentarilywe only consider top $50 \%$ of viewing instances when sorted by gaze duration for this analysis. Results show that in four of the five presentations considered (talks no. $3,5,7,12$ ) scientific elements constitute the majority of these most viewed elements. Against the backdrop of our findings regarding visibility and taking into account that the visual attention of the viewers can only lie on a limited number of elements, this analysis shows a clear preference for scientific content over entertainment and hybrid elements.

On the basis of gaze data, it can therefore be said concerning RQ3 that in terms of both pure visibility and the viewing rate, entertainment content garnered considerably less attention than scientific content. Accordingly, with regard to visual attention allocation, there are no empirical indications that scientific content is displaced by a focus on entertainment, as is sometimes claimed by science slam critics. However, further analyses would be necessary to explore the reasons for the differences in viewing rates which e.g., might be influenced by the varying complexity of the scientific and entertainment material.

\section{Conclusions}

Our evaluation of various empirical data gathered with regard to science slams paints a clear picture concerning the compatibility of scientific content and entertainment:

1) Entertainment is cited as a key reason for attending science slams, closely followed by an interest in science itself and the desire to learn something (cf. Section 5.1);

2) In line with these findings, two-thirds of presenters cite fun and enjoyment as the major personal motivation to participate in a science slam. For half of all slammers, the desire to educate is a key concern, while for one quarter, the goals of entertaining and educating are on an equal footing (cf. Section 5.1);

3) Viewers do not perceive entertaining presentations as devoid of scientific content and therefore unscientific - in fact, the opposite tends to be true (cf. Section 5.2.1);
4) Both in terms of pure visibility and viewing rates, the entertaining elements of the science slam were considerably less prevalent than the scientific elements (cf. Section 5.2.2).

In light of the foregoing, science slams would appear suitable for conveying scientific content, despite the fact that audiences rate their entertainment value as high (cf. Section 5.2.1). This explorative study did not find evidence for the assertion that science slams are a "populistic" presentation form at odds with genuine scientific understanding. Rather, the results suggest that science slams should actually be characterized as a form that accords equal value to science and entertainmentthat they represent a form of "edutainment" in a positive sense. Although the empirical analyses of this study consider science slams only, the results of the reception data also shed light on other forms of presentation with strong similarities to the science slam, such as famelab or TED: An entertaining presentation may still contain substantial scientific content. And, more fundamentally, entertainment and scientific content are not natural antipodes, but may interact in such a way that science finds its way to recipients in a pleasant form (Lederman, 2016).

It should be noted, however, that both the survey responses and the eye-tracking data were gathered at just three selected science slam events. In addition, eyetracking data are not available for all 20 presentations, thus reducing the pool of data for analysis. Furthermore, only gaze surveys by one spectator could be analysed for each presentation.

Aside from these data limitations, a further limitation concerns the focus on visual attention data, which was necessitated by the research method. The analysis of visual attention does not allow for direct inference on information transfer, processing and ultimately learning (Schumacher, 2012, p. 115). As this is the first reception study on science slams, we consciously chose an explorative approach to show a holistic picture of this form of presentation. To address these other questions, a further study, building on the results presented here, would need to work with a more experimental laboratory setting. This would allow for interviewing test persons immediately following the reception of a science slam presentation or for recording the transmission of structural knowledge by means of concept mapping (Gehl, 2013).

Furthermore, at this stage we did not include a detailed analysis of the presenters and their oral communications. These are additional key factors for the reception of presentations, as indicated by the high viewing rates the presenters receive in our analysis, and are a further necessity for investigating information transfer. A first linguistic study on the exemplary science slam presentation by Reinhard Remfort has been conducted by Hanauska (in press), the next steps would be to expand the linguistic corpus and connect with the data presented here. Future research could potentially seek to gather real-time response measurements, 
as is performed in research on political communication (Waldvogel \& Metz, 2017): Viewers of science slam presentations could be asked to rate the degree to which a talk is entertaining on a continuous basis.

In order to address the deficit in evaluation research brought up e.g., by Weingart and Joubert (2019, cf. Section 1) and to carry out in-depth comparative analyses, various science communication formats would have to be examined with a similar mix of methods. In addition to the aforementioned famelab and TED, science cafés, pub science events, and science festivals would be suitable forms for further investigation.

\section{Acknowledgments}

The research project "Science in Presentations" is funded by the Klaus Tschira Foundation and carried out by the National Institute for Science Communication (NaWik) together with the Karlsruhe Institute of Technology (KIT). We would like to thank Leilah Jätzold, Yannic Scheuerman, and Clara Weiß for their support during data collection and analysis.

\section{Conflict of Interests}

One of the authors of this article (Philipp Schrögel) was moderator of the science slam in Karlsruhe and was therefore not involved in data collection for this event. Beyond that, the authors declare no conflicts of interest.

\section{Supplementary Material}

Supplementary material for this article is available online in the format provided by the authors (unedited).

\section{References}

Aksakal, N. (2015). Theoretical view to the approach of the edutainment. Procedia-Social and Behavioral Sciences, 186, 1232-1239.

Anderson, C. (2016). TED talks: The official TED guide to public speaking. Boston, MA: Houghton Mifflin Harcourt.

Bente, G. (2004). Erfassung und Analyse des Blickverhaltens [Recording and analysis of gaze behavior]. In R. Mangold (Ed.), Lehrbuch der Medienpsychologie [Textbook of media psychology] (pp. 297-324). Göttingen: Hogrefe Verlag für Psychologie.

Böhmert, C., Niemann, P., Hansen-Schirra, S., \& Nitzke, J. (in press). Wen verstehen wir besser? Eine vergleichende Rezeptionsstudie zu Kurzmeldungen von Journalisten und Wissenschaftlern [Who do we understand better? A comparative reception study on short reports from journalists and scientists]. In J. Milde, I. C. Vogel, \& M. Dern (Eds.), Intention und Rezeption von Wissenschaftskommunikation [Intention and reception of science communication]. Köln: Herbert von Halem Verlag.
Boyette, T., \& Ramsey, J. R. (2019). Does the messenger matter? Studying the impacts of scientists and engineers interacting with public audiences at science festival events. Journal of Science Communication, 18(2), 1-16. https://doi.org/10.22323/2.18020202

Bucher, H.-J. (2005). Ist das Internet 'ready' für seine Nutzer? Online-Angebote zwischen Gebrauchstauglichkeit und Kommunikationsqualität [Is the internet 'ready' for its users? Online offerings between usability and communication quality]. In M. Jäckel \& F. Haase (Eds.), In medias res: Herausforderung Informationsgesellschaft [In medias res: The challenge of the information society] (pp. 81-116). München: Kopaed.

Bucher, H.-J. (2012). Grundlagen einer interaktionalen Rezeptionstheorie: Einführung und Forschungsüberblick [Basics of an interactional theory of reception: Introduction and research overview.]. In H.-J. Bucher \& P. Schumacher (Eds.), Interaktionale Rezeptionsforschung: Theorie und Methode der Blickaufzeichnung in der Medienforschung [Interactional reception research: Theory and method of gaze recording in media research] (pp. 17-50). Wiesbaden: Springer VS.

Bucher, H.-J., \& Niemann, P. (2012). Visualizing science: The reception of powerpoint presentations. Visual Communication, 11(3), 283-306.

Bucher, H.-J., \& Niemann, P. (2015). Medialisierung der Wissenschaftskommunikation: Vom Vortrag zur multimodalen Präsentation [Medialization of science communication: From lecture to multimodal presentation]. In M. S. Schäfer, S. Kristiansen, \& H. Bonfadelli (Eds.), Wissenschaftskommunikation im Wandel [Science communication in transition] (pp. 68-101). Köln: Herbert von Halem Verlag.

Bucher, H.-J., Niemann, P., \& Krieg, M. (2010). Die wissenschaftliche Präsentation als multimodale Kommunikationsform. Empirische Befunde zu Rezeption und Verständlichkeit von Powerpoint-Präsentationen [The scientific presentation as a multimodal form of communication: Empirical findings on the reception and intelligibility of powerpoint presentations]. In H.-J. Bucher, T. Gloning, \& K. Lehnen (Eds.), Neue Medien, neue Formate: Ausdifferenzierung und Konvergenz in der Medienkommunikation [New media, new formats: Differentiation and convergence in media communication] (pp. 375-406). Frankfurt: Campus.

Bucher, H.-J., \& Schumacher, P. (2006). The relevance of attention for selecting news content: An eyetracking study on attention patterns in the reception of print-And online media. Communications, 31(3), 347-368.

Canovan, C. (2019). "Going to these events truly opens your eyes." Perceptions of science and science careers following a family visit to a science festival. Journal of Science Communication, 18(1), 1-8. https:// doi.org/10.22323/2.18020201

Cohen, J. (1988). Statistical power analysis for the behav- 
ioral sciences (2nd ed.). Hillsdale, NJ: L. Erlbaum.

Eisenbarth, B., \& Weißkopf, M. (2012). Science Slam: Wettbewerb für junge Wissenschaftler [Science slam: Competition for young scientists]. In B. Dernbach, C. Kleinert, \& H. Münder (Eds.), Handbuch Wissenschaftskommunikation [Science communication handbook] (pp. 155-163). Wiesbaden: Springer VS.

Gehl, D. (2013). Vom Betrachten zum Verstehen. Die Diagnose von Rezeptionsprozessen und Wissensveränderungen bei multimodalen Printclustern [From contemplation to understanding: The diagnosis of reception processes and knowledge changes in multimodal print clusters]. Wiesbaden: Springer Fachmedien.

Geise, S. (2011). Eyetracking in der Kommunikations-und Medienwissenschaft: Theorie, Methode und kritische Reflexion [Eyetracking in communication and media studies: Theory, method and critical reflection]. SCM Studies in Communication and Media, 2011(2), 149-263.

Goldstein, J. H., \& McGhee, P. E. (1972). The psychology of humor: Theoretical perspectives and empirical issues. New York, NY, and London: Academic Press.

Griem, J. (2018). Die wahren Abenteuer liegen woanders [The real adventures lie elsewhere]. Forschung, 43(4), 2-5.

Hanauska, M. (in press). Und unterhaltsam soll es auch noch sein...Sprachliche Strategien der Erzeugung von Unterhaltsamkeit in Science-Slams [And it should also be entertaining...Linguistic strategies for generating entertainment in science slams]. In P. Niemann, L. Bittner, C. Hauser, \& P. Schrögel (Eds.), Science Slam. Multidisziplinäre Perspektiven auf eine populäre Form der Wissenschaftskommunikation [Science slam: Multidisciplinary perspectives on a popular form of science communication]. Wiesbaden: Springer VS.

Hill, M. (2015). Science Slam und die Geschichte der Kommunikation von wissenschaftlichem Wissen an außeruniversitäre Öffentlichkeiten [Science slam and the history of the communication of scientific knowledge to non-university audiences]. In J. Engelschalt \& A. Maibaum (Eds.), Aufder Suche nach den Tatsachen: Proceedings der 1. Tagung des Nachwuchsnetzwerks 'INSIST' [In search of the facts: Proceedings of the 1st Conference of the 'INSIST' Network of Young Scientists] (pp. 127-141). Retrieved from http://insist-network.com/wp-content/uploads/ 2016/04/Hill-Science-Slam-Engeschalt-2016.pdf

Jensen, E., \& Buckley, N. (2014). Why people attend science festivals: Interests, motivations and self-reported benefits of public engagement with research. Public Understanding of Science, 23(5), 557-537.

Just, M. A., \& Carpenter, P. A. (1980). A theory of reading: From eye fixations to comprehension. Psychological Review, 87(4), 329-354.

Kessler, S. H., \& Zillich, A. F. (2018). Searching online for information about vaccincation: Assessing the influence of user-specific cognitive factors using eyetracking. Health Communication, 34(10), 1150-1158.

Klaue, M. (2015). Science slams-Contra. Forschung \& Lehre, 22(7/15), 543.

Lederman, J. (2016, March 29). Science slams could be the future of communication research. Popular Science. Retrieved from https://www.popsci. com/science-slams-could-be-future-communicatingresearch

Nahrstedt, W. (2002). Lernort Erlebniswelt: Neue Formen informeller Bildung in der Wissensgesellschaft, Endbericht des Forschungsprojektes-Erlebnisorientierte Lernorte der Wissensgesellschaft [Experienceoriented learning places: New forms of informal education in the knowledge society, final report of the research project-Experience-oriented learning places of the knowledge society]. Bremen: Institut für Freizeitwissenschaft und Kulturarbeit.

Niemann, P. (2015). Die Pseudo-Medialisierung des Wahlkampfs: Eine rezipientenorientierte Analyse zweier Onlinewahlkämpfe politischer Parteien [The pseudo-medialization of the election campaign: A recipient-oriented analysis of two online election campaigns of political parties]. Wiesbaden: Springer VS.

Niemann, P., Bittner, L., Hauser, C., \& Schrögel, P. (in press). Forms of science presentation in public settings. In M. Dascal, A. Leßmöllmann, \& T. Gloning (Eds.), Science communication. Berlin and Boston, MA: de Gruyter.

Niemann, P., \& Krieg, M. (2011). Von der Bleiwüste zur Diashow: Zur Rezeption zentraler Formen wissenschaftlicher Präsentationen [From the lead desert to the slide show: On the reception of central forms of scientific presentations]. Zeitschrift für Angewandte Linguistik, 54(1), 111-143.

Niemann, P., Schrögel, P., \& Hauser, C. (2017). Präsentationsformen der externen Wissenschaftskommunikation: Ein Vorschlag zur Typologisierung [Presentation forms of external science communication: A proposal for typologization]. Zeitschrift Für Angewandte Linguistik, 67(1), 81-113.

Okan, Z. (2003). Edutainment: Is learning at risk? British Journal of Educational Technology, 34(3), 255-264.

Pinto, B., Marçal, D., \& Vaz, S. G. (2015). Communicating through humour: A project of stand-up comedy about science. Public Understanding of Science, 24(7), 776-793.

Pinto, B., \& Riesch, H. (2017). Are audiences receptive to humour in popular science articles? An exploratory study using articles on environmental issues. Journal of Science Communication, 16(4), 1-15. https:// doi.org/10.22323/2.16040201

Riesch, H. (2015). Why did the proton cross the road? Humour and science communication. Public Understanding of Science, 24(7), 768-775.

Rotboim, A., Hershkovitz, A., \& Laventman, E. (2019). Pos- 
itive vs. negative framing of scientific information on Facebook using peripheral cues: An eye tracking study of the credibility assessment process. Interdisciplinary Journal of e-Skills and Lifelong Learning, 15, 81-103.

Schmermund, K. (2018). Mit der eigenen Forschung auf der Clubbühne [With your own research on the club stage]. Forschung \& Lehre. Retrieved from https:// www.forschung-und-lehre.de/zeitfragen/mit-dereigenen-forschung-auf-der-clubbuehne-523

Schneider, F. M., Bartsch, A., \& Gleich, U. (2015). Spaß, Spannung...Denkanstöße? Hedonische und eudaimonische Gratifikationen, Bewertungen und Folgen der Rezeption von Stefan Raabs Sendung "Absolute Mehrheit" [Fun, excitement...Food for thought? Hedonic and eudaimonic gratifications, evaluations and consequences of the reception of Stefan Raab's programme "Absolute Majority"]. Studies in Communication and Media, 4(1), 53-68.

Schramm, H. (2019). Was ist eigentlich Unterhaltung? Annäherung an die Sphinx der Medienrezeptionsund Medienwirkungsforschung [What is entertainment anyway? Approaching the sphinx of media reception and media effects research]. In H. Schramm, J. Matthes, \& C. Schemer (Eds.), Emotions meet cognitions (pp. 35-52). Wiesbaden: Springer VS.

Schrögel, P., Niemann, P., Bittner, L., \& Hauser, C. (2017). Präsentationen in der externen Wissenschaftskommunikation: Formen \& Charakteristika [Presentations in external science communication: Forms \& characteristics] (Work Report No. 3). Karlsruhe: KIT Nachwuchsgruppe Science in Presentations. Retrieved from http://wmk.itz.kit.edu/ downloads/SIP_Arbeitsberichte_3.pdf

Schumacher, P. (2009). Rezeption als Interaktion: Wahrnehmung und Nutzung multimodaler Darstellungsformen im Online-Journalismus [Reception as interaction: Perception and use of multimodal forms of presentation in online journalism]. Baden-Baden: Nomos.

Schumacher, P. (2012). Blickaufzeichnung in der Rezeptionsforschung: Befunde, Probleme und Perspektiven [Gaze recording in reception research: Findings, problems and perspectives]. In H.-J. Bucher \& P. Schumacher (Eds.), Interaktionale Rezeptionsforschung: Theorie und Methode der Blickaufzeichnung in der Medienforschung [Interactional reception research: Theory and method of gaze recording in media research] (pp. 111-134). Wiesbaden: Springer VS.

Sugimoto, C. R., Thelwall, M., Larivière, V., Tsou, A., Mongeon, P., \& Macaluso, B. (2013). Scientists popularizing science: Characteristics and impact of TED talk presenters. PloS One, 8(4), e62403. https://doi.org/ 10.1371/journal.pone.0062403

Thiel, T. (2018, September 21). Grundlagenforschung:
Ihre Mission heißt Innovation [Basic research: Your mission is innovation]. FAZ.NET. Retrieved from https://www.faz.net/1.5793170

Veatch, T. C. (1998). A theory of humor. Humor, 11(2), 161-215.

Vorderer, P., \& Reinecke, L. (2012). Zwei-ProzessModelle des Unterhaltungserlebens: Unterhaltung im Schnittstellenbereich hedonischer und nonhedonischer Bedürfnisbefriedigung [Two-process models of entertainment experience: Entertainment at the interface of hedonic and non-hedonic needs satisfaction]. In L. Reinecke \& S. Trepte (Eds.), Unterhaltung in neuen Medien: Perspektiven zur Rezeption und Wirkung von Online-Medien und interaktiven Unterhaltungsformaten [Entertainment in new media: Perspectives on the reception and impact of online media and interactive entertainment formats] (pp. 12-29). Köln: Herbert von Halem Verlag.

Vorderer, P., \& Reinecke, L. (2015). From mood to meaning: The changing model of the user in entertainment research. Communication Theory, 25(4), 447-453.

Waldvogel, T., \& Metz, T. (2017). Real-Time-ResponseMessungen [Real-time response measurements]. In S. Jäckle (Ed.), Neue Trends in den Sozialwissenschaften [New trends in the social sciences] (pp. 307-331). Wiesbaden: Springer VS.

Weingart, P., \& Joubert, M. (2019). The conflation of motives of science communication: Causes, consequences, remedies. Journal of Science Communication, 18(3), 1-13. https://doi.org/10.22323/ 2.18030401

Weinmann, C. (2019). The normative value of political entertainment: Deliberative antecedents and consequences of media users' entertainment experiences. Studies in Communication and Media, 8(2), 135-170.

Wildemann, K. (2011). Wissenschaft wie Poesie [Science as poetry]. Nachrichten aus der Chemie, 59(4), 431-432.

Wirth, W. (2014). Zur Rezeption von Infotainment: Informations-und Unterhaltungserleben als Konstituenten der Infotainment-Rezeption [On the reception of infotainment: Information and entertainment experience as constituents of infotainment reception]. In Unterhaltungsforschung: Vol. 8. Politische Unterhaltung-Unterhaltende Politik. Forschung zu Medieninhalten, Medienrezeption und Medienwirkungen [Entertainment research: Vol. 8. Political entertainment-Entertainment politics. Research on media content, media reception and media effects] (pp. 57-93). Köln: Herbert von Halem Verlag.

Wirth, W., \& Schramm, H. (2005). Media and emotions. Communication Research Trends, 24(3), 2-43.

Zarkadakis, G. (2010). Famelab: A talent competition for young scientists. Science Communication, 32(2), 281-287. 


\section{About the Authors}

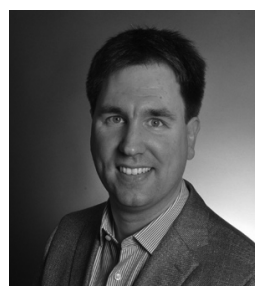

Philipp Niemann is the Scientific Head of the National Institute for Science Communication (NaWik) in Karlsruhe, Germany, and Leader of the research project "Science in Presentations." He received his PhD in Media Studies in 2014 from the University of Trier, Germany. His research interests include multimodal media communication, audience research, science communication, and political communication.

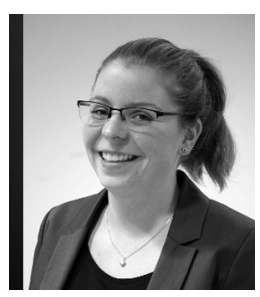

Laura Bittner received her MA in Science Communication in 2018 from Karlsruhe Institute of Technology (KIT), Germany, where she's currently working as a Researcher at the Department of Science Communication in the research project "Science in Presentations." Her research centers around forms for external science communication; further interests are the communication of uncertainty and nanochemistry.

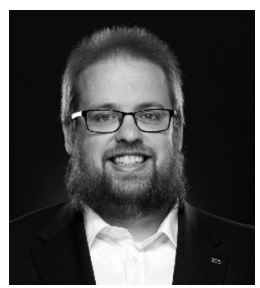

Philipp Schrögel is a Science Communication Researcher in the project "Science in Presentations" and Head of the research project "Science for All" at Karlsruhe Institute of Technology (KIT), Germany. He received his Diploma in Physics from the University of Erlangen-Nuremberg, Germany, and his Master's in public policy from the Harvard Kennedy School of Government, USA. He also works as a freelancer in science communication. His focus in research and practice lies on participatory, inclusive, and creative approaches to science communication.

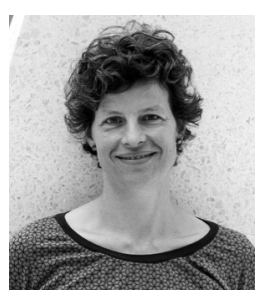

Christiane Hauser is a Researcher at the Department of Science Communication at Karlsruhe Institute of Technology (KIT), Germany, where she works in the research project "Science in Presentations." Furthermore, she studies science communicators as intermediate actors and their networks within Higher Education and Research Institutions. Throughout all projects she has a strong focus on quantitative and qualitative empirical methods and their assessment. 